\title{
Polymorphisms and Protein Expressions of Glutathione S-Transferase M1 and T1 in Non-Small Cell Lung Cancer
}

\section{Küçük Hücreli Dışı Akciğer Kanserinde Glutatyon S-Transferaz M1 veT1 Polimorfizmleri ve Protein İfadeleri}

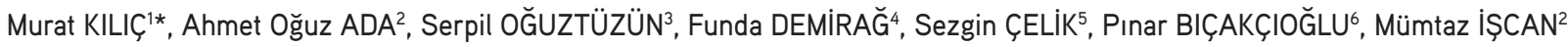 \\ 'Ankara University, Vocational School of Health Services, Department of Pharmacy Services, Ankara, Turkey \\ ${ }^{2}$ Ankara University, Faculty of Pharmacy, Department of Pharmaceutical Toxicology, Ankara, Turkey \\ ${ }^{3}$ Kırıkkale University, Faculty of Arts and Sciences, Department of Biology, Kırıkkale, Turkey \\ ${ }^{4}$ Atatürk Chest Diseases and Thoracic Surgery Training and Research Hospital, Clinic of Pathology, Ankara, Turkey \\ ${ }^{5}$ Yıldız Technical University, Faculty of Arts and Sciences, Department of Molecular Biology and Genetics, İstanbul, Turkey \\ ${ }^{6}$ Atatürk Chest Diseases and Thoracic Surgery Training and Research Hospital, Clinic of Thoracic Surgery, Ankara, Turkey
}

\begin{abstract}
Objectives: The deletion polymorphisms of glutathione S-transferase (GST) GSTM1 and GSTT1 genes result in the absence of the corresponding protein, which decreases the detoxification of carcinogens. Studies evaluating polymorphisms and protein expressions in the same patients are limited. Therefore, in this study, we aimed to investigate the association between polymorphisms and protein expressions of GSTM1 and GSTT1 in lung tissues of patients with non-small cell lung cancer (NSCLC).

Materials and Methods: For protein expression and gene deletion studies, tumor and surrounding tumor free (normal) tissue of 33 patients with NSCLC were used. In paraffin-embedded tissues, immunohistochemistry was used to detect protein expressions, and multiplex polymerase chain reaction amplification was used to identify gene deletions.

Results: GSTM1 and GSTT1 protein expressions were not detected in patients with GSTM1 and GSTT1 gene deletions, whereas protein expressions were detected in lung tissues of all patients carrying GSTM1 and GSTT1 genes. The protein expression level of GSTT1 was 2.0-fold higher in tumors of patients lacking GSTM1 genes than those with GSTM1 genes ( $p=0.018$ ). Protein expression of GSTM1 was statistically higher in tumor tissues than in normal tissues of patients with GSTM1 genes ( $p=0.001$ ).

Conclusion: These results show that a) there is an association between gene deletions and protein expressions of GSTM1 and GSTT1 in patients with NSCLC, b) in the absence of GSTM1 genes, enhancement of expression of GSTT1 in tumors is likely to show that GSTT1 increases its capacity to detoxify the toxic electrophiles in tumors, and c) GSTM1 protein expression is higher in tumors compared with normal lung tissues of patients with NSCLC.
\end{abstract}

Key words: GSTM1, GSTT1, polymorphism, protein expression, non-small cell lung carcinoma

öz

Amaç: Glutatyon S-transferaz (GST) GSTM1 ve GSTT1 genlerinde delesyon polimorfizmleri, karsinojenlerin detoksifikasyonunu azaltan ilgili enzimlerin yokluğuna neden olur. Aynı hastalarda polimorfizm ve protein ifadelerinin değerlendirildiği çalışmalar sınırlıdır. Bu nedenle, bu çalıșmada, küçük hücreli dışı akciğer kanser (KHDAK) hastalarının akciğer dokularında, GSTM1 ve GSTT1 polimorfizmleri ile protein ifadeleri arasındaki ilişkinin incelenmesini amaçladık.

Gereç ve Yöntemler: Protein ekspresyon ve gen delesyon çalışmaları için, 33 KHDAK'li hastanın arşiv dokularından elde edilen tümörlü ve çevresindeki normal doku çiftleri kullanıldı. Parafine gömülü dokularda, protein ekspresyonlarını belirlemek için immünohistokimyasal metod, gen delesyonlarını belirlemek için multipleks polimeraz zincir reaksiyonları yöntemi kullanıldı.

Bulgular: GSTM1 ve GSTT1 gen delesyonlarına sahip hastalarda GSTM1 ve GSTT1 protein ifadeleri bulunmazken, GSTM1 ve GSTT1 genlerini taşıan tüm hastaların akciğer dokularında protein ifadeleri saptanmıştır. GSTT1'in protein ifadesi, GSTM1 geninden yoksun olan hastaların tümünde, GSTM1 genine sahip olanlardan 2.0 kat daha yüksek olduğu gözlenmiştir ( $p=0.018$ ). GSTM1'in protein ifadesi, GSTM1 genine sahip hastaların tümör dokularında, normal dokularından istatistiksel olarak daha yüksek belirlenmiştir ( $\mathrm{p}=0.001)$.

*Correspondence: E-mail: muratkilic_genetic@yahoo.com, Phone: +90 5445669577 ORCID-ID: orcid.org/0000-0002-1377-2021

Received: 09.02.2017, Accepted: 23.03.2017

๑Turk J Pharm Sci, Published by Galenos Publishing House. 
Sonuç: Bu sonuçlar, a) KHDAK'li hastaların GSTM1 ve GSTT1 protein ifadeleri ile gen delesyonları arasında bir ilişkinin olduğunu, b) GSTM1 geninin yokluğunda, tümör dokularında GSTT1 protein ifadesinin artışı bu dokularda GSTT1'in toksik elektrofilikleri detoksifiye etme kapasitesini arttırma eğiliminde olduğunu ve c) KHDAK'li hastaların normal dokularına kıyasla tümörlü dokularında GSTM1 protein ifadesinin daha yüksek olduğunu göstermektedir.

Anahtar kelimeler: GSTM1, GSTT1, polimorfizm, protein ifadesi, küçük hücreli dışı akciğer kanseri

\section{INTRODUCTION}

Lung cancer is one of the leading causes of cancer deaths in the world and it is an increasing public health problem, particularly in men. Histologically, lung tumors constitute two major groups. In general, approximately $20 \%$ of cases are smallcell lung cancer (SCLC) and nearly $80 \%$ are non-small cell lung cancer (NSCLC), - the most frequently seen form of lung cancer. NSCLC has three types: adenocarcinoma, squamous cell carcinoma, and large cell carcinoma. ${ }^{2}$

It was reported that cigarette smoke in particular, which contains carcinogenic xenobiotics such as polycyclic aromatic hydrocarbons, nitrosamines and aldehydes, increases carcinogenic DNA adducts in patients with NSCLC, suppresses tumor suppressor genes (such as p53), and causes aggressive tumor generation by mutations and decreases survival in these patients. ${ }^{3}$ However, the increasing incidence of lung cancer among smokers and non-smokers suggests the possible cause of different etiologic factors other than tobacco smoking. ${ }^{4}$ Among the risk factors, expression and genetic polymorphisms of xenobiotic metabolizing enzymes involved in the metabolism of carcinogens, namely phase I and phase II enzymes, have been reported to be associated with inter-individual variability in response to carcinogens. ${ }^{5-7}$

Glutathione S-transferases (GSTs), one of the phase II complex supergene family enzymes, play a major role in the detoxification of xenobiotics including carcinogens and chemotherapeutics. ${ }^{8}$ Hence, they also have important roles in chemoresistance. ${ }^{9}$ Cytosolic GSTs exist in seven classes GSTA, GSTM, GSTP, GSTS, GSTT, GSTO, and GSTZ; many isoenzymes have been described within these classes. ${ }^{10}$ These GSTs are expressed polymorphically, which may lead to wide inter-individual variation in the metabolic activation of carcinogens, and toxicity and efficacy of drugs, particularly the chemotherapeutics. ${ }^{8,9,11,12}$

GSTM1 and GSTT1 have deletion polymorphisms that result in the absence of their corresponding enzymes. The associations between their polymorphisms and risk of lung cancer has been studied in various populations. However, some studies revealed an association between GSTM1 $1^{13,14}$ and GSTT1 15 polymorphism and lung cancer risk, whereas others found no relation with respect to GSTM18,16 and GSTT1., 8,17

Studies with respect to the expression of GSTM1 and GSTT1 in lung tissues of NSCLC are scarce and their results are contradictory. ${ }^{18,19}$ Likewise, studies evaluating the combination of polymorphisms and protein expressions of GSTs in the same patients are limited, and the results are inconclusive or even conflicting. ${ }^{20,21}$ Nakajima et al. ${ }^{21}$ (1995) found an association between GSTM1 expression and polymorphism i.e. patients with GSTM1 null genotype had no detectable GSTM1 protein in their lungs, whereas all patients who possessed this gene expressed
GSTM1 protein in lung. However, this correlation was not noted by Cantlay et al. ${ }^{20}$

Moreover, the absence of one GST gene might influence the level of the other GST, which is important for a better understanding of inter-individual variation in response to carcinogens and chemotherapeutics. In line with this, the absence of GSTM1 had also shown to affect the expression of other GST (GSTM3-3) level significantly in the lung. ${ }^{21}$

On the other hand, the potential of GSTs as a useful tumor marker has been well established. For example, GSTP1 is the major GST isoform in the lung coupled with its increased expression in lung tumors than in normal lung tissues, which renders GSTP1 protein useful as a tumor marker for lung cancer. ${ }^{20,22}$ Although, not as high and frequent as GSTP1, GSTM1 and GSTT1 are also expressed in normal human lung tissues. ${ }^{18,20,23,24}$ Nevertheless, this does not exclude the possibility of their being promising useful markers for lung cancer. Thus, studies in this regard are needed.

In this study, we aimed to demonstrate whether a) polymorphisms and protein expressions of GSTM1 and GSTT1 correlate in lung tissues of patients with NSCLC, b) the absence of GSTM1 or GSTT1 gene might influence the protein expression level of the other, and c) there exists GSTM1 and GSTT1 protein expression differences between tumor and normal tissues of patients that may render them potentially useful tumor markers for NSCLC.

\section{MATERIALS AND METHODS}

\section{Patients}

For immunohistochemical and genetic polymorphism studies, tumor and surrounding tumor-free normal paraffin-embedded pairs of tissues obtained from 33 patients with NSCLC who had not received chemotherapy or radiotherapy were obtained from the archives of the pathology department of Atatürk Chest Diseases and Thoracic Surgery Training and Research Hospital (Ankara, Turkey), and the study was approved by the local ethics committee.

\section{DNA isolation from paraffin-embedded tissues}

DNA used for polymorphic analysis was isolated from paraffinembedded tissues of patients using a DNA purification kit purchased from Zymo Research (Irvine, CA, USA) in accordance with the manufacturer's instructions. The isolated DNA samples were stored at $-20^{\circ} \mathrm{C}$ until use.

\section{Genetic polymorphism analysis of GSTM1 and GST1}

GSTM1 and the GSTT1 genetic polymorphism analyses were determined using multiplex polymerase chain reaction (PCR) method. ${ }^{25}$ In brief, isolated DNA was amplified in a $50 \mu \mathrm{L}$ reaction mixture containing $200 \mu \mathrm{M}$ deoxynucleotide mix, 10x 
Standard Taq Reaction Buffer, $0.5 \mathrm{mM} \mathrm{MgC1}, 2.5$ units Taq DNA polymerase and 50 pmol of each GSTM1 primer: 5' GAA CTC CCT GAA AAG CTA AAG C and 5' GTT GGG CTC AAA TAT ACG GTG G; and GSTT1 primers, 5'-TIC CTT ACT GGT CCT CAC ATC TC and 5'-TCA CCG GAT CAT GGC CAG CA. The CYP1A1 gene was co-amplified using the primers 5'-GAA CTG CCA CTT CAG CTG TCT and 5'-CAG CTG CAT TTG GAA GTG CTC as internal controls to prove successful PCR. The PCR conditions consisted of an initial melting temperature of $94^{\circ} \mathrm{C}$ (5 min) followed by 35 cycles of melting $\left(94^{\circ} \mathrm{C}, 2 \mathrm{~min}\right.$ ), annealing $\left(59^{\circ} \mathrm{C} 1 \mathrm{~min}\right)$ and extension $\left(72^{\circ} \mathrm{C} 1 \mathrm{~min}\right)$ with a final extension step $\left(72^{\circ} \mathrm{C}\right)$ of $10 \mathrm{~min}$. The PCR products of GSTT1, GSTM1, and CYP1A1 genes were analyzed using 2\% agarose gel electrophoresis. GSTM1 and GSTT1 genes were detected through the presence or absence of a band at 215 bp (GSTM1) and a band at 480 bp (GSTT1). A band at 312 bp corresponding to CYP1Al gene was always present and used as an internal control for PCR amplification.

\section{Immunohistochemistry}

A semi-quantitative evaluation of immunohistochemical staining for GSTM1 and GSTT1 was assessed as previously described in the method of Oguztüzun et al. ${ }^{19}$ (2010). Polyclonal rabbit antibodies against human GSTM1 and GSTT1 with no cross-reactivity with other GSTs were obtained from Abcam (Abcam-Cambridge, MA, USA). These antibodies are also suitable for immunohistochemical analysis of formalin-fixed paraffin- embedded tissues according to the manufacturer (Abcam-Cambridge, MA, USA). For immunohistochemical staining, 4- $\mu m$-thick sections from each formalin-fixed paraffin-embedded lung cancer tissue were used. Tissue sections were deparaffinized in xylene, rehydrated in graded series of alcohol, and immersed in distilled water. Endogenous peroxidase activity was blocked by incubating the sections in $1 \%$ hydrogen peroxide ( $\mathrm{v} / \mathrm{v}$ ) in methanol for 10 minutes at room temperature (RT). The sections were subsequently washed in distilled water for $5 \mathrm{~min}$, and antigen retrieval was performed for 3 min using $0.01 \mathrm{M}$ citrate buffer $(\mathrm{pH}$ 6.0) in a domestic pressure cooker. The sections were transferred in $0.05 \mathrm{M}$ Tris$\mathrm{HCl}$ ( $\mathrm{pH}$ 7.6) containing $0.15 \mathrm{M}$ sodium chloride (TBS). After washing in water, the sections were incubated at RT for 10 min with super block (SHP125) (ScyTek Laboratories, USA) to block nonspecific background staining. The sections were then covered with the primary antibodies diluted 1:100 for antiGSTM1 and 1:200 for anti-GSTT1 (Abcam, USA). After washing in TBS for $15 \mathrm{~min}$, the sections were incubated at RT for biotinylated link antibody (SHP125) (ScyTek Laboratories, USA). Then, treatment was followed with Streptavidin/HRP complex (SHP125) (ScyTek Laboratories, USA). Diaminobenzidine was used to visualize peroxidase activity in the tissues. Nuclei were lightly counterstained with hematoxylin, and then the sections were dehydrated and mounted. Both positive and negative controls were included in each run. TBS was used in place of the primary antibody for negative controls. Immunohistochemically stained sections were examined using light microscopy without knowing the clinical information of the patients, and the distribution, localization, and characteristics of immunostaining were recorded. Brown color in the cytoplasm of the epithelial cells was evaluated as positive staining. Scoring was performed by two authors independently without knowledge of patient data. Scoring differences between the observers were resolved by consensus. Staining intensity was graded as; 0 for none, 1 for weak, 2 for moderate, and 3 for strong staining.

\section{Statistical analysis}

MINITAB 14 statistical software (MINITAB release 14.12.0, MINITAB INC. State College, Pennsylvania, United States) was used for statistical evaluations. In tumor and normal tissues, the differences between protein expressions were investigated using the Mann-Whitney $U$ test. The results were considered as significant for $p<0.05$.

\section{RESULTS}

The characteristics of the 33 patients with NSCLC are shown in Table 1. The mean age of the patients was $57 \pm 7$ years. The majority of patients $(28 / 33,85 \%)$ was male. Regarding histologic subtypes, 58\% (19/33) of the patients with NSCLC had squamous cell carcinoma (SCC), and 42\% (14/33) had adenocarcinoma (AC). Some $76 \%(25 / 33)$ of the patients with NSCLC were smokers.

The GSTM1 and GSTT1 gene deletion frequencies in patients were $69.70 \%$ (23/33) and 33\% (11/33), respectively; 30\% (10/33) and $66.67 \%(22 / 33)$ of the patients were carriers of the GSTM1 and GSTT1 genes, respectively.

Figures 1 and 2 show the immunohistochemistry of GSTs in lung tumors and normal tissues using polyclonal antibodies. When

\section{Table 1. Characteristics of 33 patients with NSCLC}

\begin{tabular}{|c|c|c|}
\hline Characteristics & & mber of patients (\%) \\
\hline Total & 33 & \\
\hline Age & & \\
\hline & $<57$ & $15(45 \%)$ \\
\hline & $>57$ & $18(55 \%)$ \\
\hline Sex & & \\
\hline & Male & $28(85 \%)$ \\
\hline & Female & $5(15 \%)$ \\
\hline Histology & & \\
\hline & Squamous cell carcinoma & $19(58 \%)$ \\
\hline & Adenocarcinoma & $14(42 \%)$ \\
\hline Stage at diagn & & \\
\hline & Stage I & $14(42 \%)$ \\
\hline & Stage II & $11(33 \%)$ \\
\hline & Stage III & $8(24 \%)$ \\
\hline Smoking status & & \\
\hline & Never & $8(24 \%)$ \\
\hline & Current & $25(76 \%)$ \\
\hline
\end{tabular}


tumor and normal lung tissues were matched and the level of protein expressions of GSTM1 and GSTT1 were assessed, GSTM1 and GSTT1 expression were not observed in patients with GSTM1 and GSTT1 gene deletions. However, staining of cells with GSTM1 and GSTT1 antibodies revealed the presence of GSTM1 and GSTT1 proteins in tumors and normal tissues of patients carrying the GSTM1 and GSTT1 genes, as shown in Figures 1a, 1c, 2a, and 2c. Cells stained with GSTM1 and GST1 antibodies showed positivity with varying intensities for GSTM1 and GSTT1 in 100\% (10/10) and 100\% (22/22) of tumors, and in $30 \%(3 / 10)$ and $68 \%(15 / 22)$ of normal lung tissues, respectively. Specific immunostaining of tissue sections was absent when the antibody was replaced in the immunohistochemical procedure by TBS, as shown in Figure 1b, 1d, 2b, and 2d.

The protein expression differences of GSTM1 and GSTT1 in tumor and normal tissues of patients with GSTM1+, GSTT1+, GSTM1+/GSTT1-, GSTT1+/GSTM1- and GSTM1+/GSTT1+ are given in Table 2 . When staining intensity was assessed, the majority of tumor samples $(80 \%, 8 / 10)$, had higher GSTM1 expression than their respective normal lung tissues. However, in $41 \%(9 / 22)$ of sample pairs, GSTT1 expression was higher in tumor than normal lung tissue.

In addition, the protein expression level of GSTM1 was found significantly higher (6.33-fold) in tumor tissue than in normal tissues of patients with GSTM1+ gene $(p=0.001)$. The difference in GSTT1 expression between tumor tissues and normal tissues of patients with GSTT1+ was not statistically significant $(p=0.589)$.

It should also be noted that in normal tissues, the level of expression of GSTT1 exceeded that of GSTM1 by 5.3fold $(1.59 \pm 0.27$ and $0.30 \pm 0.15$, respectively). No significant

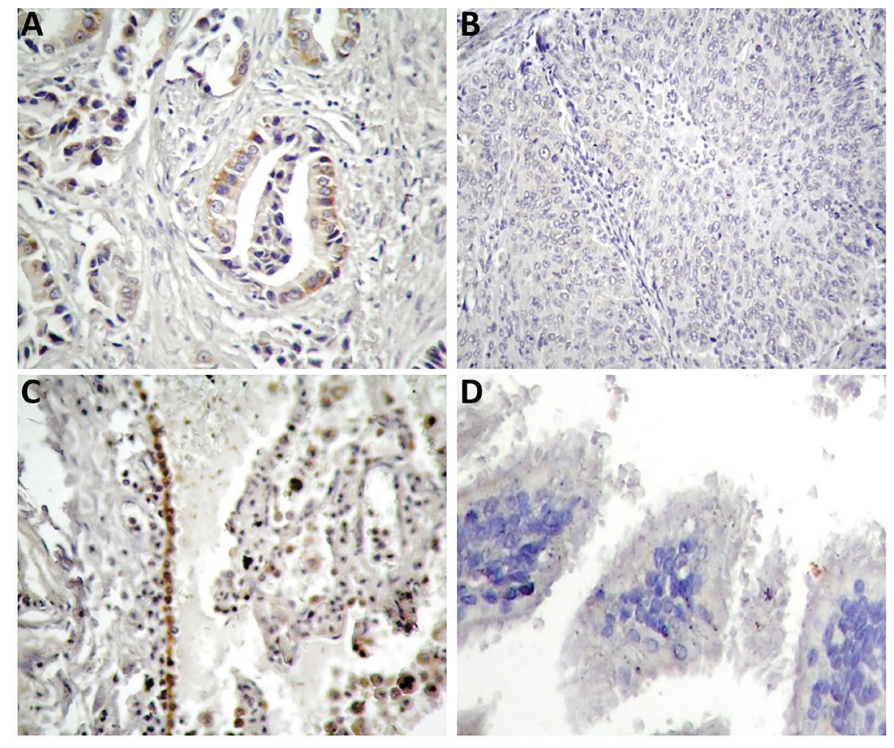

Figure 1. Immunohistochemical staining of GSTM1 protein in tumors [Panels: (a) with antibody $\times 400$, (b) without antibody, with TBS $\times 400$ ) and normal lung tissues [Panels: (c) with antibody $x$ 400, (d) without antibody, with TBS $x$ 400] (hematoxylin counterstain) difference, however, was noted between tumor protein levels of GSTT1 and GSTM1 (1.82 \pm 0.19 vs. $1.90 \pm 0.28)$.

It was observed that GSTM1 expression was remarkably (2.67fold) higher in tumors than normal tissue of patients with GSTM1+/GSTT1- genotypes. However, the difference was not significant ( $p=0.117$ ). Also, no significant difference was noted between the mean scores of GSTT1 of tumor and normal lung tissue of patients carrying GSTM1-/GSTT1+ genotypes ( $p=0.491$ ) (Table 2). In patients carrying both GSTM1 and GSTT1 genes, the level of expression of GSTM1 was statistically higher in tumor tissues than in normal tissues $(p=0.012)$, whereas no significant difference was noted for GSTT1 expression between these tissues $(p=0.999)$.

GSTT1 protein level was about 2.06-fold higher in tumors of patients carrying GSTM1-/GSTT1+ genotypes than in those carrying GSTM1+/GSTT1+ genotypes $(p=0.019)$. However, tumor GSTM1 protein level was not significantly different between GSTM1+/GSTT1- and GSTM1+/GSTT1+ genotypes ( $p=0.347$ ) as shown in Table 2.

\section{DISCUSSION}

In our study, the expressions of GSTM1 and GSTT1 proteins in lung correlated perfectly with the genotypes and were not detectable in patients without GSTM1 and GSTT1 genes, whereas all patients who possessed these genes expressed GSTM1 and GSTT1 proteins in lung. The results of our study in regard to GSTM1 are in line with those of Nakajima et al. ${ }^{21}$ (1995), but in contrast to those of Cantlay et al. ${ }^{20}$ (1994). In addition, the present study also showed that protein and polymorphism association also exists for GSTT1 in human lung.

The absence of one GST gene might influence the expression level of the other GST, which is important for a better
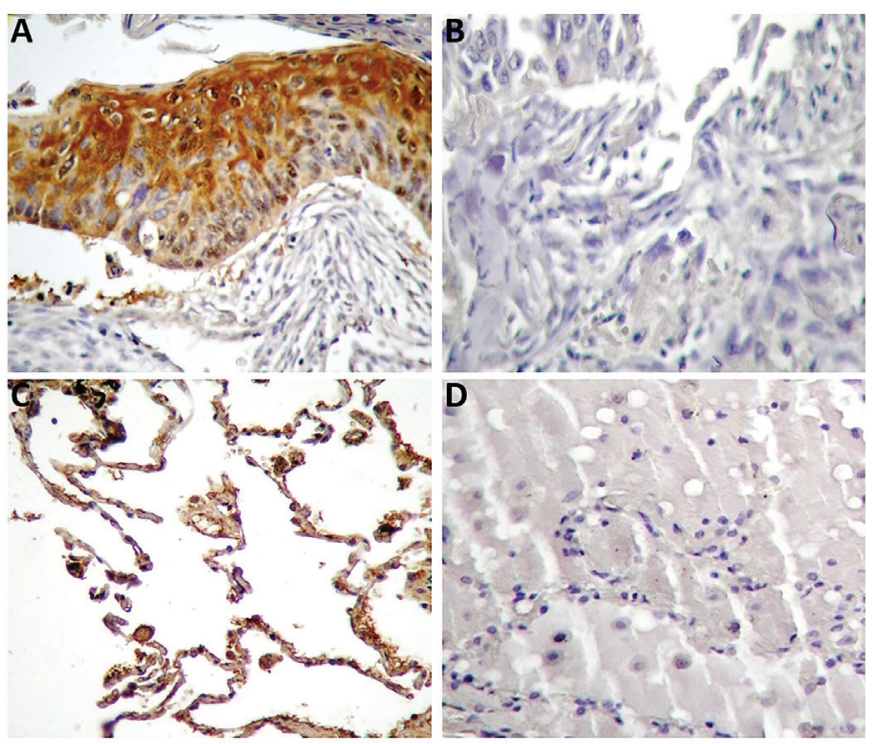

Figure 2. Ilmmunohistochemical staining of GSTT1 protein in tumors [Panels: (a) with antibody $x$ 400, (b) without antibody, with TBS $\times 400$ ] and normal lung tissues [Panels: (c) with antibody $x$ 400, (d) without antibody, with TBS $x$ 400] (hematoxylin counterstain) 
Table 2. Protein expression differences of GSTM1 and GSTT1 in tumor and normal tissues of patients with GSTM1+, GSTT1+, GSTM1+/ GSTT1-, GSTT1+/GSTM1- and GSTM1+/GSTT1+

\begin{tabular}{|c|c|c|c|c|c|c|c|}
\hline \multirow[t]{2}{*}{ Genotype } & \multirow[b]{2}{*}{$\mathrm{n}$} & \multicolumn{2}{|c|}{ GSTM ${ }^{1}$} & \multirow{2}{*}{$\begin{array}{c}\mathrm{R}^{1} \\
\mathrm{p} \text { value }\end{array}$} & \multicolumn{2}{|c|}{ GSTT $^{1}$} & \multirow{2}{*}{$\begin{array}{c}R^{1} \\
p \text { value }\end{array}$} \\
\hline & & Tumor & Normal & & Tumor & Normal & \\
\hline GSTM1+ & 10 & $\begin{array}{c}1.90 \pm 0.28^{\mathrm{a}} \\
(1-3)^{\mathrm{b}}\end{array}$ & $\begin{array}{c}0.30 \pm 0.15 \\
(0-1)\end{array}$ & $\begin{array}{c}6.33 \\
0.001\end{array}$ & & & \\
\hline GSTT1+ & 22 & & & & $\begin{array}{c}1.82 \pm 0.19 \\
(1-3)\end{array}$ & $\begin{array}{c}1.59 \pm 0.27 \\
(0-3)\end{array}$ & $\begin{array}{c}1.14 \\
0.589\end{array}$ \\
\hline GSTM1-/GSTT1+ & 17 & & & & $\begin{array}{c}2.06 \pm 0.22 \\
\quad(1-3)\end{array}$ & $\begin{array}{c}1.71 \pm 0.31 \\
(0-3)\end{array}$ & $\begin{array}{c}1.20 \\
0.491\end{array}$ \\
\hline GSTM1+/GSTT1+ & 5 & $\begin{array}{c}2.20 \pm 0.37 \\
(1-3)\end{array}$ & $\begin{array}{c}0.00 \pm 0.00 \\
(0-0)\end{array}$ & 0.012 & $\begin{array}{c}1.0 \pm 0.0 \\
(1-1)\end{array}$ & $\begin{array}{c}1.20 \pm 0.58 \\
(0-3)\end{array}$ & $\begin{array}{c}0.83 \\
0.999\end{array}$ \\
\hline
\end{tabular}

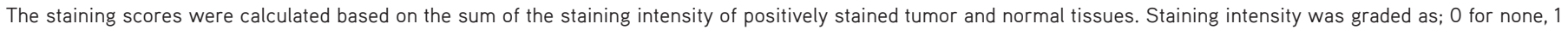

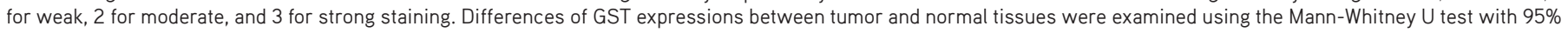
confidence level; + shows the presence of the gene; - shows the absence of the gene

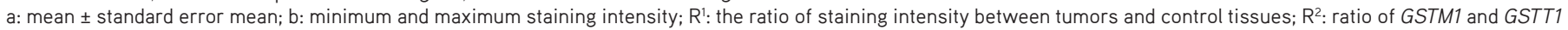

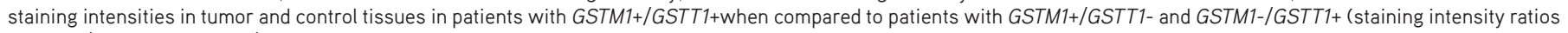
of tumor/tumor and control/control are given by the columns); p value less than 0.05 was considered statistically significant.

understanding of the inter-individual variation in response to carcinogens and chemotherapeutics. Previously, the absence of GSTM1 gene/protein was shown to significantly decrease the expression of GSTM3-3 protein levels but not of GSTP1-1 or GSTA1/2 in lungs. ${ }^{21}$ In the same study, it was also observed that the expression of GSTM2 existed only in the presence of GSTM1 genes. ${ }^{21}$ In the current study, the observation of the elevation of GSTT1 protein expression levels in tumors of patients lacking GSTM1 is also noteworthy. In the absence of GSTM1 gene, GSTT1 seems to enhance its xenobiotic detoxification capacity in lung tumors. Although we do not know the reason/s behind it, it is plausible that, as noted previously ${ }^{26}$, many GST inducers also serve as substrates of GSTs and it might therefore be expected that the absence of GSTM1 gene results in inducing agents, both endogenous and exogenous, possessing longer half-lives, thereby showing a greater induction capacity on GSTT1. However, the reasons behind it still remain to be thoroughly investigated.

In the current study, the protein expression of GSTM1 in normal lung tissues was also too low to be detected, confirming the findings of previous studies. 18,20,21,23 whereas expression of GSTT1 easily detectable in more than half of normal lung tissues, as reported previously..$^{18}$ Hence, GSTT1 protein expression was observed as higher (5.3-fold) than GSTM1 protein expression in normal lung tissue. In contrast, the protein expressions of these GSTs in tumors were detectable in all tumors almost at the same level. However, their patterns of expression between tumors and normal tissues were different. The observation of the significantly higher level of expression of GSTM1 protein compared with normal lung tissue in the current study is likely to show that GSTM1 protein could be a useful marker for NSCLC. However, Nakajima et al. ${ }^{21}$ found no significant difference between GSTM1 protein expression in tumors and normal lung tissue using immunoblot analysis. Spivack et al. $^{18}$ reach no conclusion as to whether the expression of GSTM1 protein using immunoblot analysis or mRNA levels were higher in tumor than normal lung or vice versa due to its uncommon expression in human lung. On the other hand, the lack of significant difference observed herein between the expression of GSTT1 in tumor and normal lung tissue is in contrast to the findings of a previous study ${ }^{19}$ in which GSTT1 expression was found higher in tumors than in normal tissues. These inconsistent findings could be related to the low levels of protein expressions of GSTs, especially GSTM1, in normal lung tissues, and the use of different techniques and/or antibodies in the analysis of protein expressions of these GSTs in lung tissues in these studies. Further studies are likely to be needed to clarify these inconsistencies.

\section{CONCLUSION}

In conclusion, this study shows that, a) there is an association between gene deletions and protein expression levels of GSTM1 and GSTT1 in lungs of patients with NSCLC, b) in the absence of GSTM1 gene, elevation of expression of GSTT1 in tumors is likely to show that GSTT1 increases its capacity to detoxify the toxic electrophiles in tumors, and c) GSTM1 protein expression is higher in tumors compared with normal lung tissues of patients with NSCLC. 


\section{ACKNOWLEDGEMENT}

This study was carried out under the project supported by Kırıkkale University, Coordination Unit of Scientific Research Projects (Grant number: 2011/16).

Conflict of Interest: No conflict of interest was declared by the authors.

\section{REFERENCES}

1. Oyama T, Sugio K, Uramoto H, Kawamoto T, Kagawa N, Nadaf S, Carbone D, Yasumoto K. Cytochrome P450 expression (CYP) in non-small cell lung cancer. Front Bio Sci. 2007;12:2299-2308.

2. Oyama T, Sugio K, Isse T, Matsumoto A, Nose N, Uramoto H, Nozoe T, Morita M, Kagawa N, Osaki T, Muto M, Yasumoto K, Kawamoto T. Expression of cytochrome P450 in non-small cell lung cancer. Front Bio Sci. 2008;13:5787-5793.

3. Ada AO, C Kunak S, Hancer F, Bilgen S, Suzen SH, Alpar S, Gulhan M, Kurt B, Iscan M. CYP and GST polymorphisms and survival in advanced non-small cell lung cancer patients. Neoplasma. 2010;57:512-521.

4. Choi JH, Chung HC, Yoo NC, Lee HR, Lee KH, Choi W, Lim HY, Koha EH, Kim JH, Roha JK, Kim SK, Lee WY, Kim BS. Changing trends in histologic types of lung cancer during the last decade (1981-1990) in Korea: a hospital-based study. Lung Cancer. 1994;10:287-296.

5. Harty LC, Caporaso NE, Hayes RB, Winn DM, Bravo-Otero E, Blot WJ, Kleinman DV, Brown LM, Armenian HK, Fraumeni JF Jr, Shields PG. Alcohol dehydrogenase 3 genotype and risk of oral cavity and pharyngeal cancers. J Natl Cancer Inst. 1997;89:1698-1705.

6. Katoh $\mathrm{T}$, Kaneko S, Takasawa S, Nagata N, Inatomi H, Ikemura K, Itoh H, Matsumoto T, Kawamoto T, Bell DA. Human glutathione S-transferase P1 polymorphism and susceptibility to smoking related epithelial cancer; oral, lung, gastric, colorectal and urothelial cancer. Pharmacogenetics. 1999;9:165-169.

7. Castell JV, Donato MT, Gómez-Lechón MJ. Metabolism and bioactivation of toxicants in the lung. The in vitro cellular approach. Exp Toxicol Pathol. 2005;57(Suppl 1):189-204.

8. Ada AO, Kunak SC, Hancer F, Soydas E, Alpar S, Gulhan M, Iscan M. Association between GSTM1, GSTT1, and GSTP1 polymorphisms and lung cancer risk in a Turkish population. Mol Biol Rep. 2012;39:5985-5993.

9. Lo HW, Ali-Osman F. Genetic polymorphism and function of glutathione S-transferases in tumor drug resistance. Curr Opin Pharmacol. 2007;7:367-374.

10. Hayes JD, Flanagan JU, Jowsey IR. Glutathione transferases. Annu Rev Pharmacol Toxicol. 2005;45:51-88.

11. Gonzalez FJ. Hereditary polymorphisms of human drug metabolizing enzymes and cancer susceptibility. Birth Defects Orig Artic Ser. 1990;26:17-42.
12. Di Pietro G, Magno LA, Rios-Santos F. Glutathione S-transferases: an overview in cancer research. Expert Opin Drug Metab Toxicol. 2010;6:153-170.

13. Lewis SJ, Cherry NM, Niven RM, Barber PV, Povey AC. GSTM1, GSTT1 and GSTP1 polymorphisms and lung cancer risk. Cancer Lett. 2002;180:165-171.

14. Pinarbasi H, Silig Y, Cetinkaya O, Seyfikli Z, Pinarbasi E. Strong association between the GSTM1-null genotype and lung cancer in a Turkish population. Cancer Genet Cytogenet. 2003;146:125-129.

15. Sørensen M, Autrup H, Tjønneland A, Overvad K, Raaschou-Nielsen 0 . Glutathione S-transferase $\mathrm{T} 1$ null-genotype is associated with an increased risk of lung cancer. Int J Cancer. 2004;110:219-224.

16. Carlsten C, Sagoo GS, Frodsham AJ, Burke W, Higgins JP. Glutathione S-transferase M1 (GSTM1) polymorphisms and lung cancer: a literaturebased systematic HuGE review and meta-analysis. Am J Epidemiol. 2008;167:759-774.

17. Altinisik J, Balta ZB, Aydin G, Ulutin T, Buyru N. Investigation of glutathione S-transferase M1 and T1 deletions in lung cancer. Mol Biol Rep. 2010;37:263-267.

18. Spivack SD, Hurteau GJ, Fasco MJ, Kaminsky LS. Phase I and II carcinogen metabolism gene expression in human lung tissue and tumors. Clin Cancer Res. 2003;9:6002-6011.

19. Oguztüzun S, Aydin M, Demirag F, Yazici U, Ozhavzali M, Kiliç M, Işcan M. The expression of GST isoenzymes and p53 in non-small cell lung cancer. Folia Histochem Cytobiol. 2010;48:122-127.

20. Cantlay AM, Smith CA, Wallace WA, Yap PL, Lamb D, Harrison DJ. Heterogeneous expression and polymorphic genotype of glutathione S-transferases in human lung. Thorax. 1994;49:1010-1014.

21. Nakajima T, Elovaara E, Anttila S, Hirvonen A, Camus AM, Hayes JD, Ketterer B, Vainio H. Expression and polymorphism of glutathione S-transferase in human lungs: risk factors in smoking-related lung cancer. Carcinogenesis. 1995;16:707-711.

22. Di llio C, Del Boccio G, Aceto A, Casaccia R, Mucilli F, Federici G. Elevation of glutathione transferase activity in human lung tumor. Carcinogenesis. 1988;9:335-340.

23. Anttila S, Hirvonen A, Vainio $H$, Husgafvel-Pursiainen $K$, Hayes JD, Ketterer B. Immunohistochemical localization of glutathione S-transferases in human lung. Cancer Res. 1993;53:5643-5648.

24. Mainwaring GW, Williams SM, Foster JR, Tugwood J, Green T. The distribution of theta-class glutathione S-transferases in the liver and lung of mouse, rat and human. Biochem J. 1996;318:297-303.

25. Abdel-Rahman SZ, el-Zein RA, Anwar WA, Au WW. A multiplex PCR procedure for polymorphic analysis of GSTM1 and GSTT1 genes in population studies. Cancer Lett. 1996;107:229-233.

26. Talalay $\mathrm{P}$, De Long MJ, Prochaska HJ. Identification of a common chemical signal regulating the induction of enzymes that protect against chemical carcinogenesis. Proc Natl Acad Sci U S A. 1988;85:8261-8265. 